\title{
HOW TO CREATE INDICATORS IN BALANCED SCORECARD FOR A TRAINING COMPANY?
}

\author{
MAŁGORZATA SMOLSKA \\ University of Szczecin, Faculty of Management and Economics of Services, POLAND \\ e-mail: malgorzata.smolska@wzieu.pl
}

\begin{abstract}
\begin{tabular}{l|l} 
RECEIVED & 10 December 2018
\end{tabular}
ACCEPTED 28 December 2018

JEL

CLASSIFICATION

L10, M20, 030

KEYWORDS indicators, Balanced Scorecard, training company, management

ABSTRACT The Balanced Scorecard is both a tool for implementation and monitoring of the training company's strategy. Basically, it consists of four perspectives: internal development and innovation, internal processes, client and finance. The article aims to present the main aspects of a Balanced Scorecard in a training company, focusing mainly on the process of creating indicators. The theoretical part discusses both the essence and the four key areas of Balanced Scorecard. The practical part shows an example of Balanced Scorecard for a company providing training services along with a specification of indicators to measure the achievement level of strategic objectives.
\end{abstract}

\section{Introduction}

Nowadays companies in the training industry operating in a turbulently changing environment are trying to flexibly adapt their strategy to the expectations of diverse groups of stakeholders. Thus, they are looking for strategic tools that will simplify the processes of implementation and control of strategic options. The example of such a tool is 
Balanced Scorecard, a significant signpost of a strategic implementation of the crucial goals in everyday company performance.

\section{Method}

The aim of the article is to outline the essence and areas of the Balanced Scorecard for the training company, including highlighting the process of creating indicators important in business practice. The author of the article uses the following research methods: in the theoretical part literature review; the practical part is based on author's experience in the construction of the Balanced Scorecard for enterprises in the training sector.

\section{The essence of the Balanced Scorecard - literature review}

The Balanced Scorecard, constructed by Robert S. Kaplan and David P. Norton, is a modern strategy implementation tool that facilitates translation of the company's vision, mission and strategy into operational goals for individual organizational units and employees, indicating appropriate measures of these goals, and providing full and complete information on the current situation of the company (based on financial indicators and operational measures). It can therefore be said that it is a kind of a bridge between the strategy and its implementation. It allows the strategic planner to include all the employees to develop strategies, to use their knowledge, experience and initiatives (Pierścionek, 2003, pp. 52-53).

The Balanced Scorecard can be described as a management philosophy supporting the implementation of the strategy by: formulating of strategic goals; a system of measures of the effectiveness of activities and expected values of these measures and strategic initiatives taken in the event of deviations; linking every goal and measure with the expected financial result (Olszewska, 2008, p. 238).

Using a set of measures individually matched to each process and for each employee enables to monitor the implementation of tasks related to strategic goals on an ongoing basis. Consequently, the concept of the Balanced Scorecard fills the gap existing in management systems, consisting of a lack of consistency and regularity in the process of strategy implementation.

A properly prepared Balanced Scorecard should contain: causal relationships (each target should be in the cause-and-effect chain of the company's strategy); connection with financial results (each goal should lead to a specific financial result); the factor of future success (the card should contain not only financial measures but also indicators of future success and efficiency improvement); measures to stimulate change according to certain procedures, behaviours and processes (Olszewska, 2008, pp. 238-239).

To sum up, the Balanced Scorecard is more than just a system of measuring operational efficiency. Innovative enterprises use this tool as a strategic management system, supporting the implementation of the strategy in the long term. They use the system for measuring the efficiency of the BSC (abbreviation of Balanced Scorecard) in the following key management processes: developing vision and strategy; explaining strategic goals and measures and their integration with management systems; planning, setting goals and undertaking strategic initiatives; improving systems for monitoring the implementation of the organization's strategy and learning areas (Kaplan, Norton, 2001, p. 29). 


\section{Areas of the Balanced Scorecard for a training company}

The Scorecard defines the decisive factors for the effectiveness of strategy implementation from four points of view, reflecting the key aspects affecting future success, which include (Kaplan, Norton, 2001, pp. 27-29):

Financial perspective, which focus on: monitoring the measurable, economic, effects of past activities, as well as evaluating the impact of current activities on future effects and profits.

Customer perspective, which allows strategic planner to look at the organization through the eyes of the customer. Factors such as the level of service quality and customer satisfaction can be taken into account in that perspective.

The perspective of internal processes, which allows for linking operational and innovative processes with the company's strategy and for assessing the effectiveness of these processes using performance indicators, costs, quality improvement or the number of missing items, etc.

The perspective of development and innovation concerns the company's infrastructure and employee training, allowing the assessment of intellectual capital management from the point of view of future challenges. This perspective includes: innovation indicators, expenditures on training (development) of employees, access to strategic information and information technologies.

The picture of each of the above areas is a set of certain measures/indicators. Balanced Scorecard is a measurement method that includes both an internal and external perspective, taking into account financial and non-financial measures as well as past, present and future goals. Each 'card' of the BSC represents one observed area. It is worth noting that the Balanced Scorecard provides some measurement-related capabilities that other strategic tools do not provide (Tiwana, 2003, pp. 349-350): direct connection of financial and non-financial value stimulators (profits, margins and revenues on the one hand, as well as customer satisfaction and employee competences, on the other); translating a vision into more feasible, realistic and concrete results-driven goals; the ability to define the status of the company at any time; built-in causal relationship that helps shape the e-business strategy; a sufficient number of stimulators and measures of results; the ability to communicate strategy throughout the company and to bind individual goals to the overall company strategy.

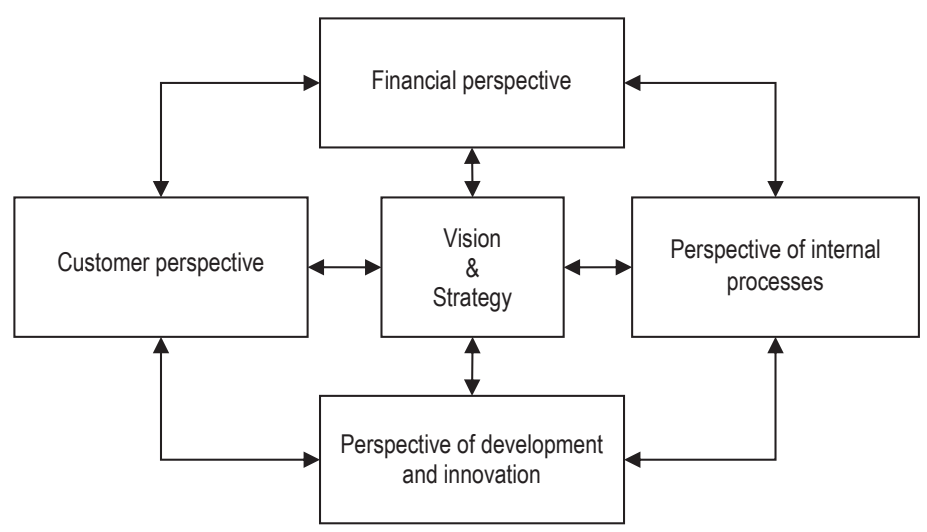

Figure 1. Diagram of the Balanced Scorecard

Source: Kaplan, Norton (2001), p. 27. 
The type and number of areas covered in the Balanced Scorecard is a matter of choice. There are four areas in the original model, but nothing stands in the way of adding more (Kaplan, Norton, 2011, p. 34). The experts creating Balanced Scorecard, however, should have in mind to not exceed seven areas to avoid information overload and dealing with less important ones. Table 1 shows examples of the main areas of the BSC perspectives for the training company.

Table 1. Examples of the main areas of the Balanced Scorecard perspectives on the example of training company

\begin{tabular}{llll}
\hline $\begin{array}{c}\text { Perspective of development } \\
\text { and innovation }\end{array}$ & \multicolumn{1}{c}{$\begin{array}{c}\text { The perspective } \\
\text { of internal processes }\end{array}$} & \multicolumn{1}{c}{ Customer perspective } & Financial perspective \\
\hline $\begin{array}{l}\text { Continuous research of market } \\
\text { needs and adjustment of the } \\
\text { training company's offer to the } \\
\text { needs of the market }\end{array}$ & $\begin{array}{l}\text { Understanding the clients' needs } \\
\text { - creating 'tailor-made' training } \\
\text { services }\end{array}$ & $\begin{array}{l}\text { Concentration on a specific } \\
\text { customer segment }\end{array}$ & $\begin{array}{l}\text { The impact of BSC on the ability } \\
\text { to control company performance } \\
\text { (sales volume, net profit, } \\
\text { company's liabilities management) }\end{array}$ \\
$\begin{array}{l}\text { Raising the qualifications } \\
\text { of trainers }\end{array}$ & $\begin{array}{l}\text { Acquiring customers via the } \\
\text { individual and institutional clients }\end{array}$ & $\begin{array}{l}\text { Internet (promotion of a training } \\
\text { company through social media) }\end{array}$ & $\begin{array}{l}\text { Debt collection policy and granting } \\
\text { discounts for regular customers } \\
\text { of the company }\end{array}$ \\
$\begin{array}{l}\text { Matching personal goals of trainers } \\
\text { with company goals }\end{array}$ & $\begin{array}{l}\text { Electronic system of payment } \\
\text { control }\end{array}$ & $\begin{array}{l}\text { Improving the profitability of sales } \\
\text { of training services through their } \\
\text { differentiation/adaptation to the } \\
\text { client's needs }\end{array}$ & $\begin{array}{l}\text { Changing the bonus system for } \\
\text { trainers }\end{array}$ \\
\hline
\end{tabular}

Source: own study.

It is worth noting that the creating of personalized Balanced Scorecard is not easy. There is also relatively limited possibility of some modeling on other companies where they are also used (Tiwana, 2003, p. 351). Unfortunately, an individual approach is often used according to construct Balanced Scorecard in business practice, based on the method of trial and error in developing own solutions, often giving rise to the need to involve employees at all levels in the company.

The basic factors describing each of the perspectives included in the card are: general objectives of the company to be achieved in the long term; specific objectives of the business unit and measures of these goals, specified in a specific norm; milestones and sub-objectives of the organizational unit to be made in the next financial year; initiatives related to the implementation of set goals; determination of responsibility for the implementation of each of the initiatives and general goals and partial objectives included in the strategy (Fałek, 2011, pp. 43-44).

\section{Examples of indicators of the Balancedl Scorecard for a training company}

The implementation of the Balanced Scorecard as a strategic management instrument is a multi-phase and long-term process. The exact process of the implementation of the BSC depends both on the specification of the company providing training services and on the market segment on which it operates. The main goal of each training company is to achieve the highest possible growth rate and the ability to adapt flexibly to dynamically changing customer needs. It should be mentioned that the detailed strategic objectives as well as the objectives measures assigned to them may differ substantially, quantitatively and qualitatively, in relation to particular training companies, their specificity of functioning and the current market situation.

Table 2 presents an example of a Balanced Scorecard for a training company. Its main elements are: strategic goals in each of the perspectives, exemplary measures of these goals and planned and current results. In the 
perspective of internal development and innovation, listed strategic goals have been formulated: development of training services and development of training programs for trainers. The main objectives of the internal processes perspective assume: the development of a new website and the use of social media portals (including Facebook) for contact with clients. The prospect of customer relations puts a special emphasis on increasing the volume and satisfaction of both regular and new customers. The whole of the above activities is to contribute to the increase in revenues from the sale of training services in the financial perspective.

Table 2. An example of a Balances Scorecard for a training company

\begin{tabular}{|c|c|c|c|}
\hline Goal & Indicator & Planned result & Current result \\
\hline \multicolumn{4}{|c|}{ Perspective of development and innovation } \\
\hline \multirow{4}{*}{$\begin{array}{l}\text { Development of the training company } \\
\text { offer }\end{array}$} & $\begin{array}{c}\text { Development of a customer relationship } \\
\text { management strategy }\end{array}$ & $\begin{array}{c}\text { Yes } \\
\text { Document until 30/04/2019 }\end{array}$ & \\
\hline & $\begin{array}{l}\text { Inclusion of potential clients - service } \\
\text { recipients in the co-creation of training } \\
\text { services }\end{array}$ & $\begin{array}{c}\text { Yes } \\
>2 \text { training products co-created by customers } \\
\text { every year }\end{array}$ & \\
\hline & Establishing cooperation with new trainers & $>2$ new trainers a year & \\
\hline & Introduction of new trainings to the offer & $>5$ new trainings a year & \\
\hline \multirow{2}{*}{$\begin{array}{l}\text { Development of training programs } \\
\text { for trainers }\end{array}$} & $\begin{array}{c}\text { Number of trainings held by trainers covered } \\
\text { by the professional skills improvement } \\
\text { program }\end{array}$ & $\begin{array}{c}\text { - minimum } 4 \text { trainings per year for each } \\
\text { trainer }\end{array}$ & \\
\hline & $\begin{array}{l}\text { Number of trainers ending the above training } \\
\text { with a good result }\end{array}$ & $>80 \%$ of the total & \\
\hline \multicolumn{4}{|c|}{ Perspective of internal processes } \\
\hline $\begin{array}{l}\text { Development of a new website by } \\
\text { a newly employed IT specialist }\end{array}$ & Number of new visits to the site & $>30$ visits per week & \\
\hline $\begin{array}{l}\text { Using social networks (Facebook) } \\
\text { to contact customers }\end{array}$ & Number of Facebook likes & $>20$ likes under $80 \%$ of total posts & \\
\hline \multicolumn{4}{|c|}{ Perspective of customer } \\
\hline \multirow{2}{*}{ New customers } & Number of new individual customers & $>100$ per year & \\
\hline & Number of new business customers & $>30$ per year & \\
\hline \multirow{2}{*}{ Regular customers } & Number of regular customers & $>25$ & \\
\hline & Increase in the number of regular customers & $>10 \%$ per annum & \\
\hline \multirow{3}{*}{ The level of customer satisfaction } & $\begin{array}{l}\text { The average assessment of a standard } \\
\text { training (in the offer for over one year) }\end{array}$ & $>4$ (on a scale from 0 to 5 ) & \\
\hline & Average rating of new trainings & $>3.5$ (on a scale from 0 to 5 ) & \\
\hline & Average grade of the trainer & $>4$ (on a scale from 0 to 5 ) & \\
\hline \multicolumn{4}{|c|}{ Perspective of finance } \\
\hline Improvement of financial results & $\begin{array}{l}\text { Increasing revenues from sales of training } \\
\text { services }\end{array}$ & $>5 \%$ per annum & \\
\hline
\end{tabular}

Source: own study.

The above-mentioned Balanced Scorecard is developed for the entire enterprise. It can be translated into objective cards for individual company departments or individual goals cards for each employee - trainer. In the process of designing a goal card, as in the construction of the Balanced Scorecard, those responsible for analyzing each of the perspectives should set strategic and detailed goals and measures of these goals, as well as the initiatives and responsibilities associated with them. Initiatives and related tasks that should be performed by the 
department/employee of the company should be assigned to individual organizational departments/employees. The measures included in the card related to the implementation of strategic goals should relate to the measurement of past events - indicators of the past, as well as factors determining the future success of the company - future indicators (Fałek, 2011, pp. 45). Table 3 presents an example of the sample card of goals for trainer $X$ in the perspective of internal development and innovation.

Table 3. A sample card of goals for the trainer $X$ in the perspective of internal development and innovation

\begin{tabular}{|c|c|c|c|c|c|}
\hline Strategic goals & Measures & Period & Specific objectives & Initiatives & Responsibility \\
\hline \multirow{2}{*}{$\begin{array}{l}\text { Develop-ment } \\
\text { of training } \\
\text { programs } \\
\text { for the trainer } X\end{array}$} & $\begin{array}{l}\text { Number of completed } \\
\text { trainings - planned } 4 \text { per } \\
\text { year }\end{array}$ & 1 year & $\begin{array}{l}\text { Development } \\
\text { of competences } \\
\text { and professional } \\
\text { qualifications }\end{array}$ & $\begin{array}{l}\text { - identification of training needs } \\
\text { of trainer } X \text {, } \\
\text { - individual development of the } \\
\text { training plan by the trainer } X \text {, } \\
\text { - participation in trainings }\end{array}$ & Trainer $X$ \\
\hline & $\begin{array}{l}\text { Average rating obtained } \\
\text { from competence tests } \\
\text { (>80\% of total points) }\end{array}$ & 1 year & $\begin{array}{l}\text { Raising competences } \\
\text { and professional } \\
\text { qualifications }\end{array}$ & $\begin{array}{l}\text { - participation in competence tests } \\
\text { (each time after the training), } \\
\text { - testing the acquired qualifications } \\
\text { in the business practice }\end{array}$ & Trainer $X$ \\
\hline
\end{tabular}

Source: own study.

At the same time, it is significant to formulate a card of goals in the financial perspective for trainer $\mathrm{X}$, as shown in Table 4.

Table 4. A sample card of goal in the financial perspective for trainer $X$

\begin{tabular}{llllll}
\hline \multicolumn{1}{c}{ Strategic goals } & \multicolumn{1}{c}{ Measures } & Period & Specific objectives & Initiatives & Responsibility \\
\hline $\begin{array}{l}\text { Improvement } \\
\text { of financial results }\end{array}$ & $\begin{array}{l}\text { Value of the volume } \\
\text { of revenues generated } \\
\text { by the trainer } X\end{array}$ & 1 year & $\begin{array}{l}\text { Increase in sales revenues } \\
\text { attributable to the trainer } X\end{array}$ & $\begin{array}{l}- \text { increase in the number of trainings } \\
- \text { improving the quality of trainings }\end{array}$ & Trainer $X$ \\
\hline
\end{tabular}

Source: own study.

Summarizing the assumptions of the BSC for the trainer - the planned objectives from the internal development and innovation prospects should enhance the implementation of the objectives from financial perspective and thus contribute to the achievement of general objectives for the entire enterprise providing training services.

\section{Conclusions}

When composing a set of indicators in Balanced Scorecard, it is worth preserving the amount of moderation - especially when the tool is used for the first time. The mistake made by many managers is to succumb to the temptation to create 'artificial' measures that look good in reports, but do not reflect the realities of business. A smaller number of indicators does not mean a worse tool, especially as the BSC, like any strategic management tool should be modified and updated over time. To sum up, the obvious conclusion is that if we are not sure whether a given indicator may be useful - next let's not put it in the BSC, having in mind that in the process of change in the 
tool we will have the opportunity to add it. A smaller number of measures also means easier monitoring system, especially if we do not use specialized IT programs.

An important advantage of BSC is the possibility of complete freedom both in terms of formulating perspectives and selection of measures allowing to assess the degree of implementation of the strategic goals of the training company. This allows strategic planner to create an individual, 'tailor-made' tool for the training company, adapted to its specifications and needs.

\section{References}

Fałek, Z. (2011). Wyważanie karta. Personel i Zarządzanie, 2 (251), 43-45.

Kaplan, R.S., Norton, D.P. (2001). Strategiczna Karta Wyników. Jak przełożyć strategię na działanie. Warszawa: Wydawnictwo Naukowe PWN.

Kaplan, R.S., Norton, D.P. (2011). Dopasowanie w biznesie. Jak stosować strategiczną kartę wyników. Gdańsk: GWP.

Olszewska, B. (2008). Zarządzanie strategiczne. Przedsiębiorstwo na progu XXI w. Wrocław: Wydawnictwo Uniwersytetu Ekonomicznego we Wrocławiu.

Pierścionek, Z. (2003). Strategie konkurencji i rozwoju przedsiębiorstwa. Warszawa: Wydawnictwo Naukowe PWN.

Tiwana, A. (2003). Przewodnik po zarządzaniu wiedzą: e-biznes i zastosowanie CRM. Warszawa: Wydawnictwo Placet.

Cite this article aS: Smolska, M. (2018). How to create indicators in balanced scorecard for a training company? European Journal of Service Management, 4 (28/2), 413-419. DOI: 10.18276/ejsm.2018.28/2-49. 